\title{
Improved Optimization Study of Integration Strategies in Solar Aided Coal-Fired Power Generation System
}

\author{
Rongrong Zhai, Miaomiao Zhao, Chao Li, Pan Peng, and Yongping Yang \\ School of Energy Power and Mechanical Engineering, North China Electric Power University, Beijing 102206, China \\ Correspondence should be addressed to Rongrong Zhai; zhairongrong01@163.com
}

Received 28 December 2014; Revised 5 June 2015; Accepted 11 June 2015

Academic Editor: Sauro Filippeschi

Copyright ( 2015 Rongrong Zhai et al. This is an open access article distributed under the Creative Commons Attribution License, which permits unrestricted use, distribution, and reproduction in any medium, provided the original work is properly cited.

\begin{abstract}
Solar aided coal-fired power generation system (SACFPGS) combines solar energy and traditional coal-fired units in a particular way. This study mainly improves the solar thermal storage system. Genetic algorithm is used to optimize the SACFPGS. The best integration approach of the system, the collector area, and the corresponding thermal storage capacity to replace each high-pressure extraction are obtained when the amount of coal saving in unit solar investment per hour is at its largest. System performance before and after the improvement is compared. Results show that the improvement of the thermal storage system effectively increases the economic benefit of the integrated system.
\end{abstract}

\section{Introduction}

The increasing severity of environment problems has resulted in the growing importance of energy conservation and emission reduction in the power industry. As a clean renewable energy, solar energy plays a crucial role in addressing this need. Solar power is divided into photovoltaic and solar thermal power generation. Solar thermal power can achieve scale utilization and match well with traditional coal-fired units and grids [1-3]. To solve the problem of high investment and operational instability in solar thermal power, some scholars proposed the concept of SACFPGS [4], a system that integrates solar energy and traditional coal-fired power generation units. From the solar thermal power system side, the steam turbine and generator of solar thermal power system can be eliminated in the SACFPGS compared to the stand-alone solar thermal power system. The cost of solar thermal power generation can be reduced to some extent. And the solar-electricity conversion efficiency in integrated system is much higher than that in solar thermal power system [5]. From the coal-fired power plant side, the coal consumption in the fuel-saving mode can be decreased when using solar energy to provide the heat demand of highpressure heater [6].

Research on SACFPGS mainly includes system integration approach [7-9], system performance analysis [10-12], optimizing design and operation [13, 14], and thermal storage system study [15-18]. Firstly, in respect of system integration approach, four different integration schemes for coal-fired power plant integrated with a parabolic trough solar field, namely, vaporization of high-pressure stream, preheating of high-pressure stream, heating of intermediate-pressure turbine inlet stream, and heating of low-pressure turbine inlet stream, were compared, and vaporization of high-pressure stream seems the most promising integration scheme [7]. Secondly, for the system performance analysis, the exergy destruction in the integrated system includes losses in combustor, collector, heat exchangers, and pump and turbines which accounts for $29.62,8.69,9.11$, and $8 \%$ of the total exergy input to the system, respectively [10]. The energy production cost for power boost mode is $75.25 € / \mathrm{MWh}$ while the same value for fuel saving is $76.01 € / \mathrm{MWh}$ [11]. Thirdly, in respect of optimizing design and operation, the solar contribution of SACFPS with five load conditions has been optimized [13]. The performance analysis of a SACFPS was done at designed point under various load conditions [14]. In addition, in the field of thermal storage system study, thermal energy storage system design methodologies and the factors to be considered at different hierarchical levels for concentrating solar power (CSP) plants are summarized [15]. The transient heat loss of molten salt thermal energy storage tanks is calculated 


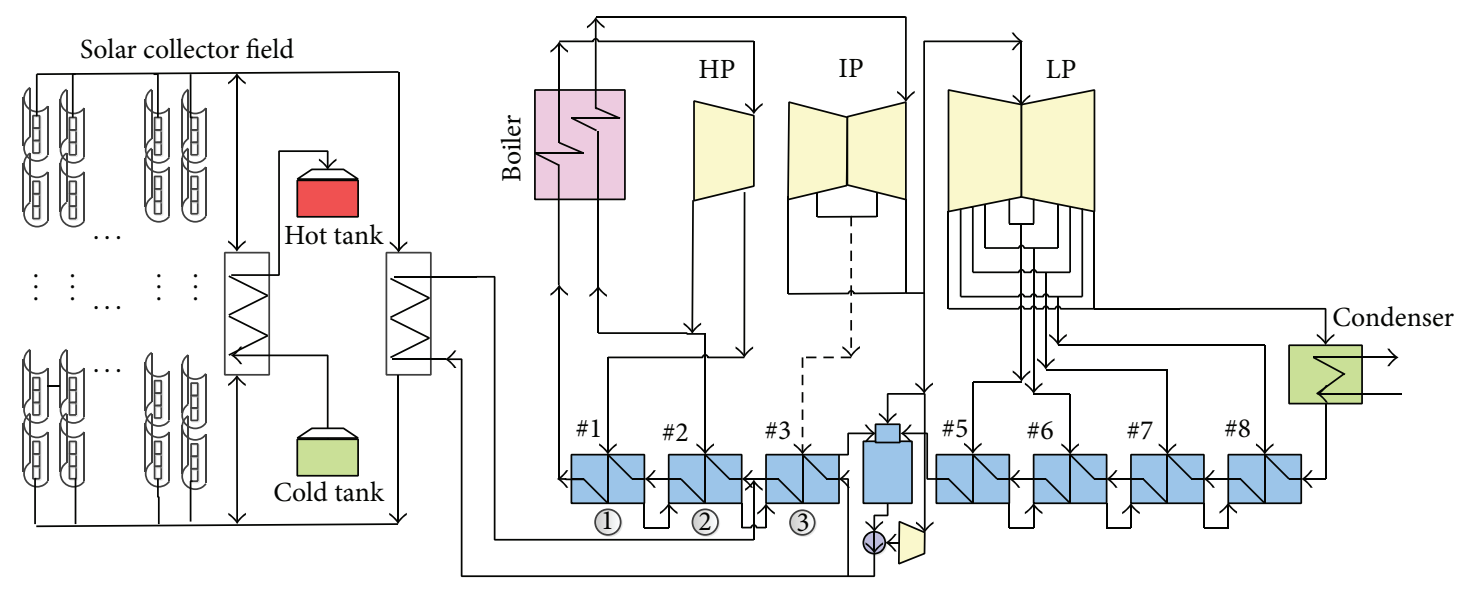

FIGURE 1: Diagram of the SACFPGS system.

[16]. The economics of thermal energy storage for CSP are analyzed [17]. The operation strategies for CSP with two-tank thermal storage are discussed [18].

The present paper is based on a SACFPGS solar collector field optimization designing study that has partially completed by us what is referred to as original system optimization [19]. In the original system genetic algorithm optimization process, the amount of coal saving in unit solar investment per hour $\left(C_{\mathrm{ACSIH}}\right)$ is considered as the objective function, and collector field area and thermal storage capacity are the variables. Reasonable optimization results have been obtained through the process. Original system optimization is a meaningful exploration in the optimization design of SACFPGS. However, thermal storage capacity is determined by the maximum value, that is, the thermal storage capacity capable of using all of the heat collected by the solar system. This design approach is not the most economical because the investment will grow with the increase in thermal storage capacity. Thus, the current study proposes an improved thermal storage designing approach by using the best value to determine the capacity of the thermal storage system. The approach cannot ensure that all the heat is used in the thermal storage system; some will still be wasted, but it can significantly improve the economics of the system.

The main originalities of this paper are as follows.

(i) The genetic algorithm is used to optimize the solar collector field area and thermal storage capacity.

(ii) The DNI data in a whole year is used to calculate the fitness of individuals; it is more reasonable than only using a designed DNI to calculate.

(iii) The optimization objective function, the amount of coal saving in unit solar investment per hour $\left(C_{\mathrm{ACSIH}}\right)$, is first proposed by the authors of this paper.

(iv) The storage capacity cannot ensure that the remaining heat of solar field after being utilized by coal-fired power plant is stored in the thermal storage system, but it can improve the $C_{\mathrm{ACSIH}}$.

\section{System Description}

The diagram of SACFPGS is shown in Figure 1. The system includes two subsystems: parabolic trough solar collector subsystem and $600 \mathrm{MW}$ coal-fired subsystem. Heat collected by the solar collector field is used to replace high-pressure extractions of the turbine. The replaced high-pressure extractions can return to the turbine and do some work. Two kinds of operation modes are widely utilized, namely, power boosting (fuel required by the boiler is the same as that required by the original coal-fired power plant) and fuel saving (output is the same as that of the original coalfired power plant). Fuel-saving operation mode is chosen in this study. The output of the integrated system is therefore $600 \mathrm{MW}$.

In this study, each of the three high-pressure extractions corresponds to a parabolic trough solar collector system. Figure 1 only shows the diagram of the third extraction which is substituted by the solar collector field. The first and second extractions are omitted; otherwise, the integrated system diagram will be large. Feedwater is pumped into the boiler after being heated in the oil-water heat exchanger.

The solar collector system mainly contains three parts: collector subsystem, thermal storage subsystem, and heat exchanger subsystem. Collector subsystem comprises a series of parabolic trough solar collectors installed from north to south and tracking from east to west. Thermal storage subsystem includes a hot molten salt tank, a cold molten salt tank, and an oil-salt heat exchanger, which is the key equipment in the heat exchanger subsystem. The oil, molten salt, and feedwater exchange heat in the corresponding circulation subsystem to achieve the goal of using solar energy to replace high-pressure extractions. There are four kinds of operation methods.

(1) When energy from the solar collector field and the heat storage tank cannot provide sufficient heat to raise feedwater temperature to the designed value of the original coal-fired power system, the system will operate originally without replacing, and absorbed solar heat will be stored in the hot molten salt tank. 
(2) When energy from the solar collector field and the heat storage tank can provide sufficient heat to raise feedwater temperature to the designed value, the high-pressure extractions of turbine will be replaced by this energy. In this condition, feedwater will be pumped initially into the oil-water heat exchanger and then into the boiler.

(3) When energy from the solar collector field can provide more heat than what is required to raise feedwater temperature to the designed value, highpressure extractions of the turbine will be replaced by this energy, and additional heat will be stored in the hot molten salt tank.

(4) When the solar collector field does not absorb enough heat, such as at night or in poor weather condition, but energy from the heat storage tank can provide enough heat to raise feedwater temperature to the designed value, then stored heat will be used to replace highpressure extractions of the turbine.

\section{Methodology}

3.1. Model Construction. The thermodynamic calculation program was written by using the MATLAB Software in this paper. Some basic thermodynamic formulas of each subsystem are shown as follows.

(i) Boiler. Boiler is one of the most important parts of coalfired power plants, and it is used to convert water into steam. According to the first law of thermodynamics, the boiler thermal balance equation can be obtained:

$$
Q_{b}=m_{b}\left(h_{b, \text { out }}-h_{b, \text { in }}\right) \eta_{b}
$$

where $Q_{b}$ : the heat absorbed by boiler, $\mathrm{kW} ; \eta_{b}$ : the thermal efficiency of boiler; $m_{b}$ : the feedwater flow, $\mathrm{kg} / \mathrm{s} ; h_{b \text {,in }}$ : the specific enthalpy of feedwater into the boiler, $\mathrm{kJ} / \mathrm{kg} ; h_{b, \text { out }}$ : the specific enthalpy of feedwater out of the boiler, $\mathrm{kJ} / \mathrm{kg}$.

(ii) Turbine. According to the position of extractions, the steam turbine is divided into nine modules. The work in each steam turbine module is shown in the following:

$$
W=m_{t}\left(h_{t, \text { in }}-h_{t, \text { out }}\right) \eta_{t}
$$

where $m_{t}$ : the steam flow, $\mathrm{kg} / \mathrm{s} ; h_{t, \text { in }}$ : the specific enthalpy of steam into the turbine module, $\mathrm{kJ} / \mathrm{kg} ; h_{t, \text { out }}$ : the specific enthalpy of steam out of the turbine module, $\mathrm{kJ} / \mathrm{kg} ; \eta_{t}$ : the relative internal efficiency of turbine modules.

(iii) Condenser. The condenser is a heat exchanger which is used to condense the turbine exhaust into water. The thermodynamic equilibrium of the condenser is shown as

$$
Q_{\text {cond }}=m_{c}\left(h_{c, \text { in }}-h_{c, \text { out }}\right) \eta_{\text {enc }}
$$

where $m_{c}$ : the condensate flow, $\mathrm{kg} / \mathrm{s} ; h_{c \text {,in }}$ : the specific enthalpy of steam into the condenser, $\mathrm{kJ} / \mathrm{kg} ; h_{c \text {,out }}$ : the specific enthalpy of steam out of the condenser, $\mathrm{kJ} / \mathrm{kg}$; $\eta_{\mathrm{enc}}$ : the efficiency of condenser.

(iv) Heater. The heater can be divided into surface-type heater and mixed-type heater. High-pressure heaters and lowpressure heaters are all surface-type heaters, while deaerator belongs to mixed-type heater. For the surface-type heaters, the heat balance equation is shown as

$$
\begin{aligned}
& {\left[m_{e}\left(h_{e}-h_{\text {deout }}\right)+m_{\text {de }}\left(h_{\text {dein }}-h_{\text {deout }}\right)\right] \eta_{\text {hfen }}} \\
& \quad=m_{\mathrm{fw}}\left(h_{\text {fwout }}-h_{\text {fwin }}\right),
\end{aligned}
$$

where $m_{e}$ : the extraction flow, $\mathrm{kg} / \mathrm{s} ; h_{e}$ : the specific enthalpy of extraction, $\mathrm{kJ} / \mathrm{kg} ; m_{\mathrm{de}}$ : the higher-pressure heater drain, $\mathrm{kg} / \mathrm{s}$; $h_{\text {dein }}$ : the specific enthalpy of higher-pressure heater drain, $\mathrm{kJ} / \mathrm{kg}$; $h_{\text {deout }}$ : the specific enthalpy of this stage drain, $\mathrm{kJ} / \mathrm{kg}$; $m_{\mathrm{fw}}$ : the feedwater flow, $\mathrm{kg} / \mathrm{s} ; h_{\mathrm{fwin}}$ : the specific enthalpy of feedwater into the heater, $\mathrm{kJ} / \mathrm{kg} ; h_{\mathrm{fwout}}$ : the specific enthalpy of feedwater out of the heater, $\mathrm{kJ} / \mathrm{kg} ; \eta_{\mathrm{hfen}}$ : the heat transfer sufficiency.

(v) Deaerator. The deaerator is used to remove the dissolved oxygen and other gases in feedwater. It can prevent and reduce the corrosion of feed water pipelines, economizer, and other ancillary equipment. The heat balance equation is shown as

$$
H_{\text {water }}=\frac{H_{\text {steam }} \cdot m_{\text {steam }}+H_{\text {feedwater }} \cdot m_{\text {feedwater }}+H_{\text {drain }} \cdot m_{\text {drain }}+H_{\text {other }} \cdot m_{\text {other }}}{m_{\text {steam }}+m_{\text {feedwater }}+m_{\text {drain }}+m_{\text {other }}},
$$

where $H_{\text {water }}$ : the specific enthalpy of feedwater out of the deaerator, $\mathrm{kJ} / \mathrm{kg} ; H_{\text {steam }}$ : the specific enthalpy of extraction into deaerator, $\mathrm{kJ} / \mathrm{kg} ; m_{\text {steam }}$ : the steam flow of turbine, $\mathrm{kg} / \mathrm{s}$; $H_{\text {feedwater }}$ : the specific enthalpy of feedwater into deaerator, $\mathrm{kJ} / \mathrm{kg} ; m_{\text {feedwater }}$ : the feedwater flow into deaerator, $\mathrm{kg} / \mathrm{s}$; $H_{\text {drain }}$ : the specific enthalpy of drain into deaerator, $\mathrm{kJ} / \mathrm{kg}$; $m_{\text {drain }}$ : the drain flow to the deaerator, $\mathrm{kg} / \mathrm{s} ; H_{\mathrm{other}}$ : the specific enthalpy of other steam or water into deaerator, $\mathrm{kJ} / \mathrm{kg} ; m_{\mathrm{other}}$ : other steam or water flow to the deaerator, $\mathrm{kg} / \mathrm{s}$.

(vi) Solar Collector Flied. Solar collector field consists of a series of parabolic trough reflective mirrors and the heatabsorbing tube. Sun light is reflected by the mirrors into the heat-absorbing tube which is located in the focus of the 
mirrors. The heat transfer oil inside the tube is used to absorb the focused heat. The heat absorbed by the solar field can be calculated as

$$
\begin{aligned}
Q_{\text {absorbed }}= & A \cdot \mathrm{DNI} \cdot \cos (\theta) \cdot \mathrm{IAM} \cdot \text { RowShadow } \\
& \cdot \text { EndLoss } \cdot \eta_{\text {field }} \cdot \eta_{\mathrm{HCE}} \cdot \text { SFAvail, }
\end{aligned}
$$

where $Q_{\text {absorbed }}$ : the heat absorbed by the solar field, W; $A$ : the solar field area, $\mathrm{m}^{2}$; DNI: the direct normal irradiation, $\mathrm{W} / \mathrm{m}^{2} ; \theta$ : the incidence angle, ${ }^{\circ}$; IAM: the correction factor of incidence angle; RowShadow: the correction factor of collector shelter; EndLoss: the correction factor of end-loss; $\eta_{\text {field }}$ : the optics correction factor of solar field efficiency; $\eta_{\mathrm{HCE}}$ : the optics correction factor of solar collector equipment; SFAvail: the ratio of solar collector and solar field.

The calculation formula of solar field investment is shown as

$$
I_{\text {solar }}=A C_{\text {solar }}
$$

where $I_{\text {solar }}$ : the investment of solar field, dollar; $C_{\text {solar }}$ : the unit cost of solar field, dollar/ $\mathrm{m}^{2}$.

(vii) Thermal Storage System. In thermal storage systems, molten salts are stored at two temperature levels defining a certain temperature difference that is used in order to charge or discharge sensible heat. The lower temperature level is defined by the molten salt freezing temperature plus a certain operation and safety offset. The so-called solar salt, a mixture of $60 \% \mathrm{NaNO}_{3}$ and $40 \% \mathrm{KNO}_{3}$, can be used between 260 and $600^{\circ} \mathrm{C}$. The salt-oil heat exchanger is used to transfer heat between molten salt and oil. The capacity and cost of thermal storage system can be obtained as (8) and (9). Consider the following:

$$
E_{\text {salt }}=1000 m_{\mathrm{HTF}} \Delta h_{\mathrm{HTF}} \eta
$$

where $E_{\text {salt }}$ : the capacity of thermal storage system, $\mathrm{MW}_{\mathrm{th}}$; $m_{\mathrm{HTF}}$ : the oil flow, $\mathrm{kg} / \mathrm{s} ; \Delta h_{\mathrm{HTF}}$ : the enthalpy change of oil, $\mathrm{kJ} / \mathrm{kg}$; $\eta$ : the efficiency of salt-oil heat exchanger. Consider the following:

$$
I_{\text {storage }}=F_{\text {salt }} E_{\text {salt }} C_{\text {salt }}+I_{0} \text {, }
$$

where $I_{\text {storage }}$ : the investment of thermal storage system, dollar; $F_{\text {salt }}$ : the factor considering there must be some salt in the tank; $C_{\text {salt }}$ : the unit cost of molten salt, dollar/MW $\mathrm{MW}_{\mathrm{th}} ; I_{0}$ : the cost of the tanks, dollar.

\subsection{Optimization Strategies. The SACFPGS system saves fuel} consumption but increases the cost of power generation. Therefore, evaluating changes in economic benefits after the introduction of solar energy into coal-fired units is an issue worthy of study. Based on the unchanged output of SACFPGS system, this paper presents an indicator to evaluate its economic benefits, that is, $C_{\mathrm{ACSIH}}$ :

$$
C_{\text {ACSIH }}=\frac{M_{\text {coalsaving }}}{\left(I_{\text {solar }}+I_{\text {storage }}\right) \cdot N},
$$

TABLE 1: The integration approach of the SACFPGS system.

\begin{tabular}{lccc}
\hline Number & $\begin{array}{c}\text { The first } \\
\text { extraction }\end{array}$ & $\begin{array}{c}\text { The second } \\
\text { extraction }\end{array}$ & $\begin{array}{c}\text { The third } \\
\text { extraction }\end{array}$ \\
\hline 1 & $\mathrm{Y}$ & $\mathrm{Y}$ & $\mathrm{Y}$ \\
2 & $\mathrm{Y}$ & $\mathrm{Y}$ & $\mathrm{N}$ \\
3 & $\mathrm{Y}$ & $\mathrm{N}$ & $\mathrm{Y}$ \\
4 & $\mathrm{~N}$ & $\mathrm{Y}$ & $\mathrm{Y}$ \\
5 & $\mathrm{Y}$ & $\mathrm{N}$ & $\mathrm{N}$ \\
6 & $\mathrm{~N}$ & $\mathrm{Y}$ & $\mathrm{N}$ \\
7 & $\mathrm{~N}$ & $\mathrm{~N}$ & $\mathrm{Y}$ \\
8 & $\mathrm{~N}$ & $\mathrm{~N}$ & $\mathrm{~N}$ \\
\hline
\end{tabular}

where $C_{\mathrm{ACSIH}}$ : the amount of coal saving in unit solar investment per hour, g/(h.dollar); $M_{\text {coalsaving }}$ : the amount of saved coal in a year, g; $N$ : operation time, h.

The cost of solar side mainly focuses on the collector field and the heat storage system. Reasonably choosing the collector field area and the storage system capacity for the SACFPGS system is thus important.

In the original system, the capacity of the heat storage system is determined by the maximum value [19]. In the current study, after the system is improved, the capacity of the heat storage system cannot guarantee that the energy absorbed by the solar collector field will all be used. The unused energy will be wasted. The improved system will have high $C_{\mathrm{ACSIH}}$ due to the increase in cost of the heat storage system as its capacity increases.

In this paper, genetic algorithm is used to optimize the integrated system. Genetic algorithm is a stochastic global search optimization method based on Darwin's theory of evolution and Mendel's genetics. This method has inherent parallelism and global optimization ability and considers the probability of optimization methods in the search process. Using probability optimization on the method, genetic algorithm can automatically acquire and guide search space optimization to achieve an optimal solution [20].

For the SACFPGS system, there are eight kinds of integration approach, as shown in Table 1. In the table, "Y" means replacing the high-pressure extraction, and " $\mathrm{N}$ " means not replacing. The aim of this study is to find the best integration approach of the system, the collector area, and the corresponding thermal storage capacity when $C_{\mathrm{ACsIH}}$ is the largest. Heat storage capacity of three heat storage tanks is denoted as ST1, ST2, and ST3. S1, S2, and S3 stand for the collector area. The schematic of the optimization process is shown in Figure 2. An initial population of individuals in the range of optimization variables is chosen randomly at first. The heat absorption of solar field and storage capacity of each individual was calculated according to the DNI in the first hour of a year. The system integration method was determined by the calculation result. Then the fitness (i.e., $C_{\mathrm{ACSIH}}$ ) of each individual was iteratively calculated by integrated system thermodynamic calculation program. Through calculating the fitness of individuals in every hour of a year, the average valve can be obtained. The next population can be generated by selection, crossover, and mutation according 


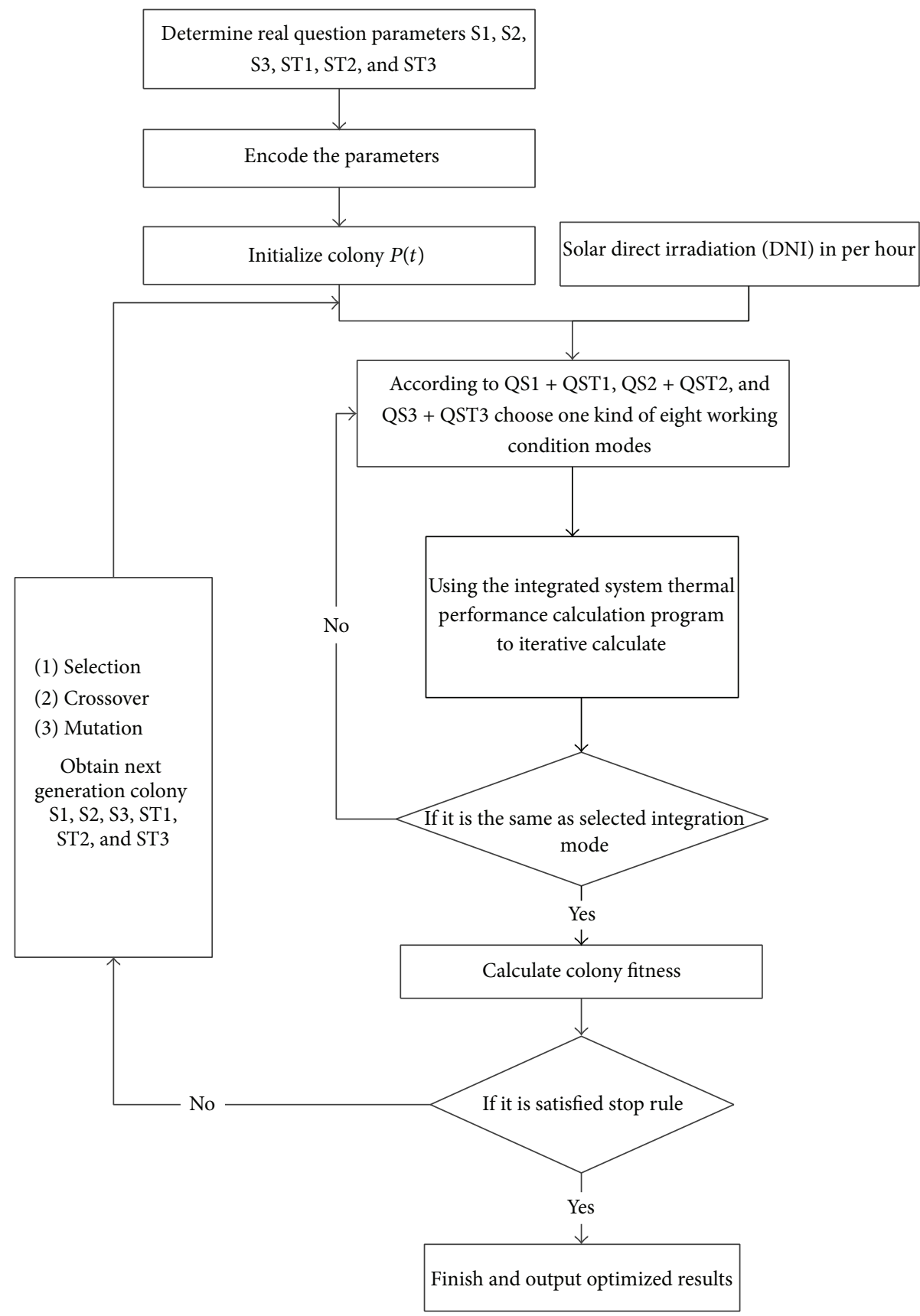

FIGURE 2: Diagram of genetic algorithm optimization.

to the average fitness of individuals. Iterative calculating until it reaches the maximum genetic algebra and output the best individual.

\section{Optimization Results}

System optimization is based on the same original coalfired units that have N600-24.2/566/566 turbines for the study. Unsaturated feedwater from the condenser enters the boiler after going through a condensate pump, four lowpressure reheaters ( $\# 5, \# 6, \# 7$, and $\# 8$ ), a deaerator, a feedwater pump, and three high-pressure reheaters (\#1, \#2, and \#3). The feedwater then absorbs heat in the boiler and becomes superheated steam. Outlet superheated steam from the boiler is transported to the high-pressure cylinder in the turbine to produce power. Steam from the high-pressure cylinder goes into the boiler being reheated to improve work capacity. Reheated steam is transported to intermediate-pressure and lower-pressure cylinders to produce power. Final exhaust is condensed in the condenser. In the solar side, the mature trough collector technology is used. The investment in the collector system is $\$ 325 / \mathrm{m}^{2}$. The investment in the heat 
TABLE 2: Optimization results of the improved system.

\begin{tabular}{|c|c|c|c|c|c|c|c|c|}
\hline $\begin{array}{l}\text { Total area } \\
\mathrm{km}^{2}\end{array}$ & $\begin{array}{c}C_{\mathrm{ACSIH}} \\
\mathrm{g} /(\mathrm{h} \cdot \text { dollar })\end{array}$ & $\begin{array}{c}\text { Storage capacity } \\
\text { MW }_{\text {th }} \\
\end{array}$ & $\begin{array}{c}\mathrm{S} 1 \\
\mathrm{~km}^{2}\end{array}$ & $\begin{array}{c}\mathrm{S} 2 \\
\mathrm{~km}^{2}\end{array}$ & $\begin{array}{c}\mathrm{S} 3 \\
\mathrm{~km}^{2} \\
\end{array}$ & $\begin{array}{r}\mathrm{ST} 1 \\
\mathrm{MW}_{\mathrm{th}}\end{array}$ & $\begin{array}{c}\mathrm{ST} 2 \\
\mathrm{MW}_{\text {th }}\end{array}$ & $\begin{array}{c}\mathrm{ST} 3 \\
\mathrm{MW}_{\mathrm{th}}\end{array}$ \\
\hline 0.1 & 0.0939 & 61.48 & 0 & 0.1 & 0 & 0 & 61.48 & 0 \\
\hline 0.2 & 0.0950 & 29.18 & 0.0757 & 0.1219 & 0.0024 & 13.47 & 14.81 & 0.90 \\
\hline 0.3 & 0.0804 & 9.42 & 0.0880 & 0.1369 & 0.0751 & 2.24 & 3.59 & 3.59 \\
\hline 0.4 & 0.0624 & 43.98 & 0.1439 & 0.1761 & 0.0800 & 9.42 & 33.21 & 1.35 \\
\hline 0.5 & 0.0524 & 26.03 & 0.0899 & 0.1956 & 0.2145 & 0 & 26.03 & 0 \\
\hline 0.6 & 0.0447 & 23.34 & 0.2470 & 0.2653 & 0.0877 & 0 & 1.35 & 21.99 \\
\hline
\end{tabular}

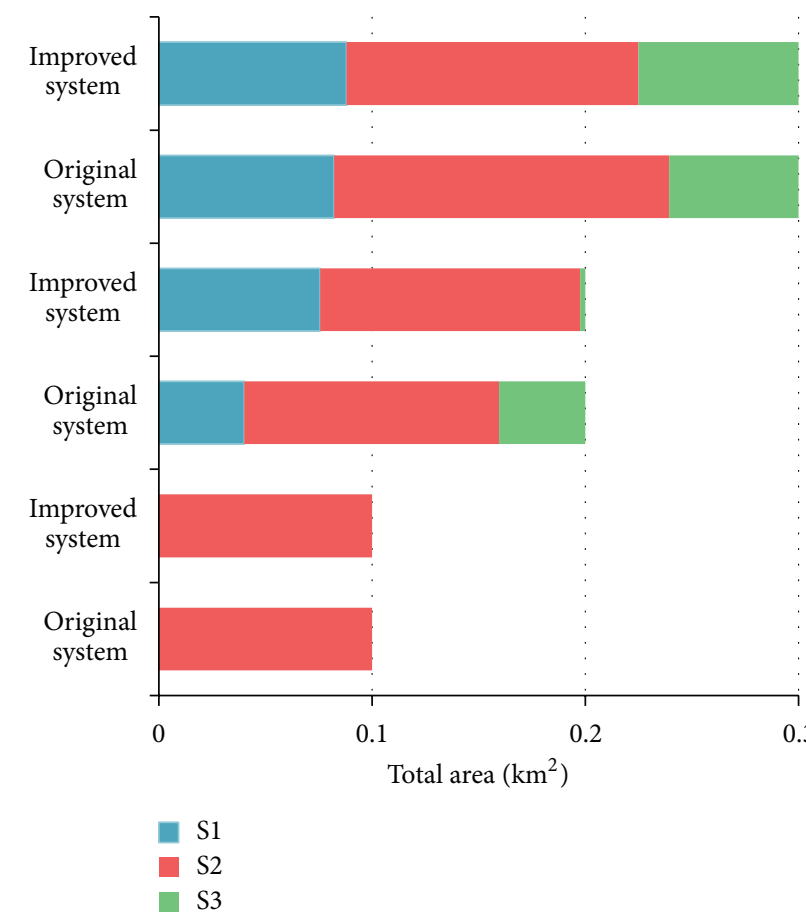

(a)

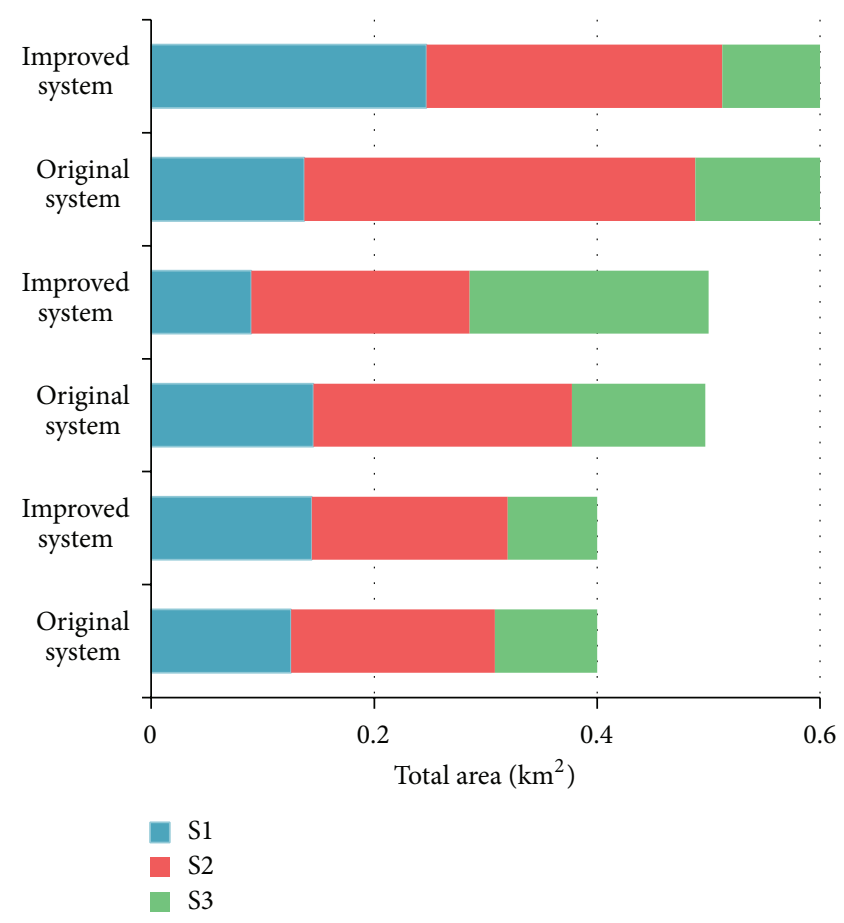

(b)

FIGURE 3: (a) Allocation relationship of S1, S2, and S3 in the original and improved systems (with total areas of $0.1,0.2$, and $0.3 \mathrm{~km}^{2}$ ). (b) Allocation relationship of S1, S2, and S3 in the original and improved systems (with total areas of $0.4,0.5$, and $0.6 \mathrm{~km}^{2}$ ).

storage system increases linearly with the increase in heat storage capacity [21].

4.1. Improved System Optimization Analysis. The SACFPGS system optimization program is developed on the basis of the MATLAB platform. $C_{\mathrm{ACSIH}}$ and other corresponding parameters are obtained when the area of the solar collector fields increases from $0.1 \mathrm{~km}^{2}$ to $0.6 \mathrm{~km}^{2}$. The results are shown in Table 2.

Table 2 shows the optimization results of the improved system. When the solar collector field area increases from $0.1 \mathrm{~km}^{2}$ to $0.2 \mathrm{~km}^{2}, C_{\mathrm{ACSIH}}$ is slightly increased to the highest level of $0.0950 \mathrm{~g} /(\mathrm{h} \cdot$ dollar $)$. When the solar collector area is over $0.2 \mathrm{~km}^{2}, C_{\mathrm{ACSIH}}$ decreases from $0.0950 \mathrm{~g} /(\mathrm{h} \cdot$ dollar) to $0.0447 \mathrm{~g} /(\mathrm{h} \cdot$ dollar) with the increase in solar collector area. Therefore, increasing the collector area cannot lead to an increase in $C_{\mathrm{ACSIH}}$. When the solar collector field area is $0.2 \mathrm{~km}^{2}, C_{\mathrm{ACSIH}}$ reaches its maximum.
In this study, when the solar collector fields have a total area of $0.1 \mathrm{~km}^{2}$, the best way to optimize the integration is by using the entire area to replace the second-stage highpressure extraction. Thus, both S1 and S3 are 0. When the solar collector field is $0.2 \mathrm{~km}^{2}$, the best way to integrate the system is when $\mathrm{S} 1$ is $0.0757 \mathrm{~km}^{2}, \mathrm{~S} 2$ is $0.1219 \mathrm{~km}^{2}$, and $\mathrm{S} 3$ is $0.0024 \mathrm{~km}^{2} . \mathrm{S} 1, \mathrm{~S} 2$, and S3 all have the appropriate areas. Table 2 indicates that the three collector fields all have their own optimal collector area when the solar collector field area increases from $0.2 \mathrm{~km}^{2}$ to $0.6 \mathrm{~km}^{2}$. S2 is always larger than $\mathrm{S} 1$ and S3. Table 2 also shows that the capacity of the heat storage system is kept in a reasonable range and does not increase with the increase in collector area.

4.2. Comparison of the Original and Improved Systems. Figures 3 and 4 show the differences of S1, S2, and S3 and ST1, ST2, and ST3 between the original system and the improved 


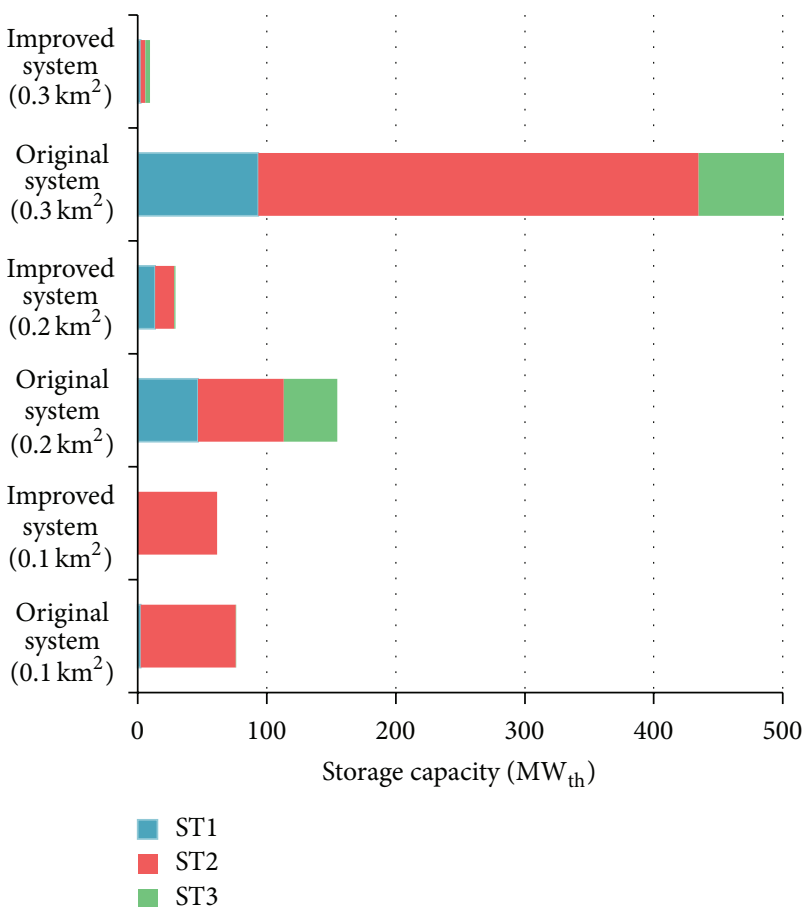

(a)

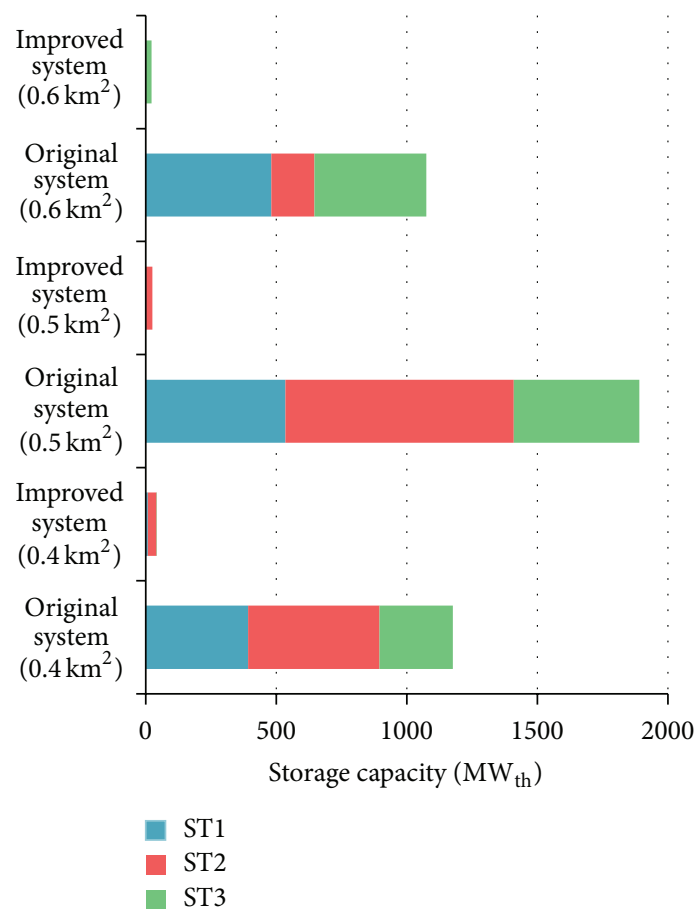

(b)

FIgURE 4: (a) Comparative relationship of ST1, ST2, and ST3 in the original and improved systems (with total areas of $0.1,0.2$, and $0.3 \mathrm{~km}^{2}$ ). (b) Comparation relationship of ST1, ST2, and ST3 in the original and improved systems (with total areas of $0.4,0.5$, and $0.6 \mathrm{~km}^{2}$ ).

system when the total area of the solar collector field increases from $0.1 \mathrm{~km}^{2}$ to $0.6 \mathrm{~km}^{2}$, respectively.

Figure 3 shows that when the total solar collector area is $0.1 \mathrm{~km}^{2}$, the best way to optimize integration for the original and improved systems is by using the entire area to replace the second-stage high-pressure extraction. When the total area of the solar collector field increases from $0.2 \mathrm{~km}^{2}$ to $0.6 \mathrm{~km}^{2}$, S1, $\mathrm{S} 2$, and S3 all have the appropriate area, but S2 is larger than S1 and S3.

Figure 4 shows the contrast of ST1, ST2, and ST3 between the original and improved systems. Heat storage capacity of the improved system is smaller than that of the original system. When the total area of the solar collector fields increases from $0.3 \mathrm{~km}^{2}$ to $0.6 \mathrm{~km}^{2}$, the decrease of storage capacity in improved system significantly reduces the investment of the heat storage system and enhances the economic benefits of the SACFPGS system. To further illustrate that the improved system has an economic advantage, the differences of $C_{\mathrm{ACSIH}}$ between the original and improved systems are shown in Figure 5.

Figure 5 shows that $C_{\mathrm{ACSIH}}$ of the improved system is higher than that of the original system when the solar collector field area increases from $0.1 \mathrm{~km}^{2}$ to $0.6 \mathrm{~km}^{2}$. This result is due to the higher heat storage capacity of the original system compared with that of the improved system. Consequently, the investment of the original system is significantly higher than the improved system. For the original system, the $C_{\mathrm{ACSIH}}$ reaches the maximum $(0.089 \mathrm{~g} /(\mathrm{h} \cdot$ dollar $))$ when the collector field has a total area of $0.1 \mathrm{~km}^{2}$. The integration approach

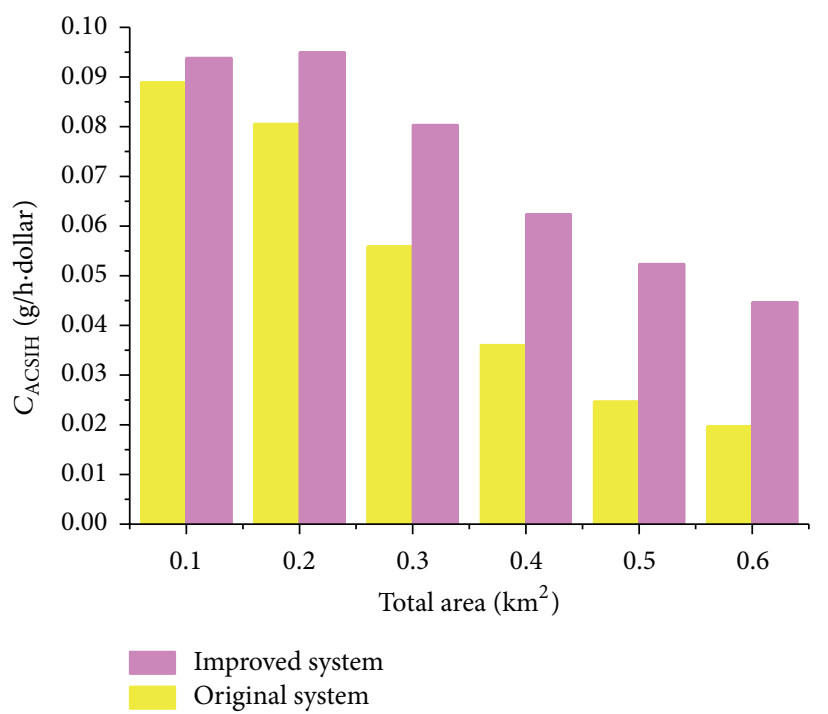

Figure 5: Comparative relationship of $C_{\mathrm{ACSIH}}$ in the original and improved systems.

is using the entire area to replace the second-stage highpressure extraction. For the improved system, the $C_{\mathrm{ACSIH}}$ reaches the maximum $(0.095 \mathrm{~g} /(\mathrm{h} \cdot \mathrm{dollar}))$ when the collector field area is $0.2 \mathrm{~km}^{2}$. The integration approach is all three high-pressure extractions being replaced. The maximum $C_{\mathrm{ACSIH}}$ of improved system is $0.006 \mathrm{~g} /(\mathrm{h} \cdot \mathrm{dollar})$ bigger than that of the original system. 


\section{Conclusion}

In this study, an improved thermal storage designing approach by using the best value to determine the capacity of the thermal storage system is proposed. It cannot ensure that the remaining heat of solar field after being utilized by coal-fired power plant is stored in the thermal storage system, but it can improve the $C_{\mathrm{ACSIH}}$. The maximum $C_{\mathrm{ACSIH}}$ of improved system is $0.006 \mathrm{~g} /(\mathrm{h} \cdot$ dollar) bigger than that of original system.

Genetic algorithm is used to optimize the improved SACFPGS system. The best integration method of the improved system is that all three high-pressure extractions are replaced. The total area of the solar collector field is $0.2 \mathrm{~km}^{2}$. Every solar collector field has areas of $0.0757 \mathrm{~km}^{2}$, $0.1219 \mathrm{~km}^{2}$, and $0.0024 \mathrm{~km}^{2}$ and thermal storage capacities of 13.47 $\mathrm{MW}_{\mathrm{th}}, 14.81 \mathrm{MW}_{\mathrm{th}}$, and 0.90 $\mathrm{MW}_{\mathrm{th}}$. While the best integration method of the original system is that only the second high-pressure extraction is replaced, the total area of the solar collector field is $0.1 \mathrm{~km}^{2}$, and the thermal storage capacity is 76.03 $\mathrm{MW}_{\text {th }}$.

The second collector area is always larger than the first and third collector areas in both original and improved systems when the total area of the solar collector field increases from $0.1 \mathrm{~km}^{2}$ to $0.6 \mathrm{~km}^{2}$.

\section{Conflict of Interests}

The authors declare that there is no conflict of interests regarding the publication of this paper.

\section{Acknowledgments}

The research work is supported by China National Natural Science Foundation (no. 51106048), the Program for 973 Project (no. 2015CB251505), and the Fundamental Research Funds for the Central Universities and the Program for 863 Project (2012AA050604) and 111 Project (B12034).

\section{References}

[1] V. S. Reddy, S. C. Kaushik, K. R. Ranjan, and S. K. Tyagi, "Stateof-the-art of solar thermal power plants-a review," Renewable \& Sustainable Energy Reviews, vol. 27, no. 6, pp. 258-273, 2013.

[2] O. Behar, A. Khellaf, and K. Mohammedi, "A review of studies on central receiver solar thermal power plants," Renewable and Sustainable Energy Reviews, vol. 23, no. 4, pp. 12-39, 2013.

[3] R. Terdalkar, H. Qian, and G. Ye, "Unique challenges in the design and operation philosophy of solar thermal power plants," Energy Procedia, vol. 49, pp. 2521-2531, 2014.

[4] E. Hu, Y. Yang, A. Nishimura, F. Yilmaz, and A. Kouzani, "Solar thermal aided power generation," Applied Energy, vol. 87, no. 9, pp. 2881-2885, 2010.

[5] R. Zhai, Y. Yang, Y. Zhu, and D. Chen, "The evaluation of solar contribution in solar aided coal-fired power plant," International Journal of Photoenergy, vol. 2013, Article ID 197913, 9 pages, 2013.

[6] Y. Yang, Q. Yan, R. Zhai, A. Kouzani, and E. Hu, "An efficient way to use medium-or-low temperature solar heat for power generation-integration into conventional power plant," Applied Thermal Engineering, vol. 31, no. 2-3, pp. 157-162, 2011.

[7] S. Gunasekaran, N. D. Mancini, R. El-Khaja, E. J. Sheu, and A. Mitsos, "Solar-thermal hybridization of advanced zero emissions power cycle," Energy, vol. 65, no. 2, pp. 152-165, 2014.

[8] Y. Yang, Y. Cui, H. Hou, X. Guo, Z. Yang, and N. Wang, "Research on solar aided coal-fired power generation system and performance analysis," Science in China, Series E: Technological Sciences, vol. 51, no. 8, pp. 1211-1221, 2008.

[9] Q. Yan, E. Hu, Y. Yang, and R. Zhai, "Evaluation of solar aided thermal power generation with various power plants," International Journal of Energy Research, vol. 35, no. 10, pp. 909922, 2011.

[10] A. Baghernejad and M. Yaghoubi, "Exergy analysis of an integrated solar combined cycle system," Renewable Energy, vol. 35, no. 10, pp. 2157-2164, 2010.

[11] G. C. Bakos and C. Tsechelidou, "Solar aided power generation of a $300 \mathrm{MW}$ lignite fired power plant combined with line-focus parabolic trough collectors field," Renewable Energy, vol. 60, no. 4, pp. 540-547, 2013.

[12] M. V. J. J. Suresh, K. S. Reddy, and A. K. Kolar, “4-E (Energy, Exergy, Environment, and Economic) analysis of solar thermal aided coal-fired power plants," Energy for Sustainable Development, vol. 14, no. 4, pp. 267-279, 2010.

[13] R. Zhai, M. Zhao, K. Tan, and Y. Yang, "Optimizing operation of a solar-aided coal-fired power system based on the solar contribution evaluation method," Applied Energy, vol. 146, pp. 328-334, 2015.

[14] H. J. Hou, Z. Y. Yu, Y. P. Yang, C. Si, L. Na, and W. Junjie, "Performance evaluation of solar aided feedwater heating of coal-fired power generation (SAFHCPG) system under different operating conditions," Applied Energy, vol. 112, no. 16, pp. 710-718, 2013.

[15] S. Kuravi, J. Trahan, D. Y. Goswami, M. M. Rahman, and E. K. Stefanakos, "Thermal energy storage technologies and systems for concentrating solar power plants," Progress in Energy \& Combustion Science, vol. 39, no. 4, pp. 285-319, 2013.

[16] F. Zaversky, J. García-Barberena, M. Sánchez, and D. Astrain, "Transient molten salt two-tank thermal storage modeling for CSP performance simulations," Solar Energy, vol. 93, no. 7, pp. 294-311, 2013.

[17] S. J. Wagner and E. S. Rubin, "Economic implications of thermal energy storage for concentrated solar thermal power," Renewable Energy, vol. 61, pp. 81-95, 2014.

[18] M. Biencinto, R. Bayón, E. Rojas, and L. González, "Simulation and assessment of operation strategies for solar thermal power plants with a thermocline storage tank," Solar Energy, vol. 103, no. 6, pp. 456-472, 2014.

[19] R. Zhai, P. Peng, Y. Yang, and M. Zhao, “Optimization study of integration strategies in solar aided coal-fired power generation system," Renewable Energy, vol. 68, no. 3, pp. 80-86, 2014.

[20] Y. J. Lei, S. W. Zhang, and X. W. Li, Genetic Algorithm Toolbox and Application, Xi'an Electronic Science and Technology University Press, Xian, China, 2005.

[21] J. M. Cabello, J. M. Cejudo, M. Luque, F. Ruiz, and K. Deb, "Optimization of the size of a solar thermal electricity plant by means of genetic algorithms," Renewable Energy, vol. 36, no. 11, pp. 3146-3153, 2011. 

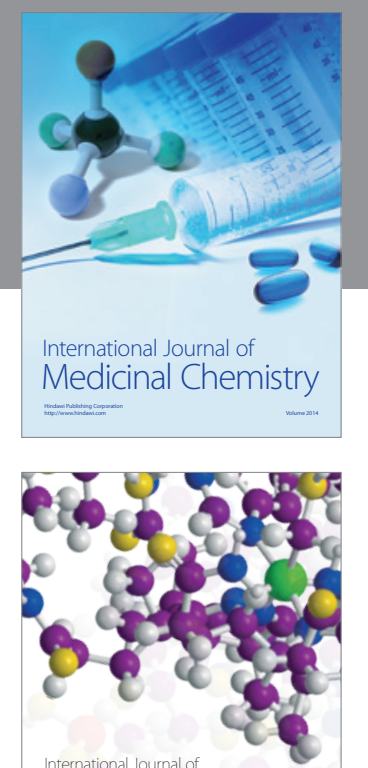

\section{Carbohydrate} Chemistry

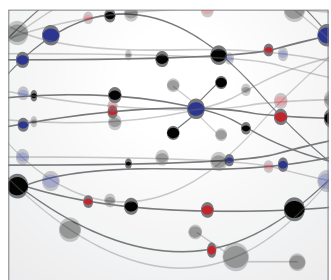

The Scientific World Journal
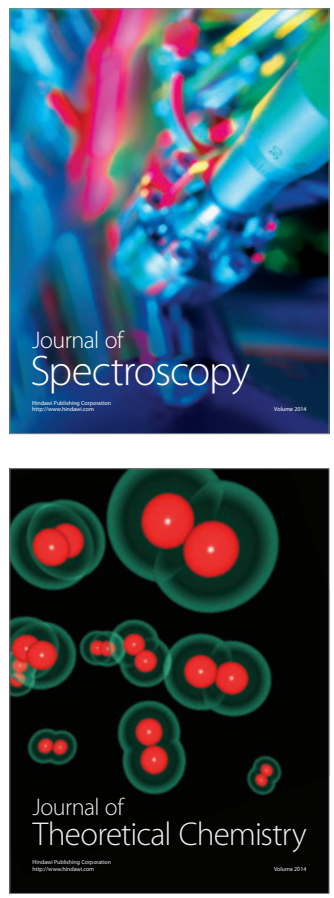
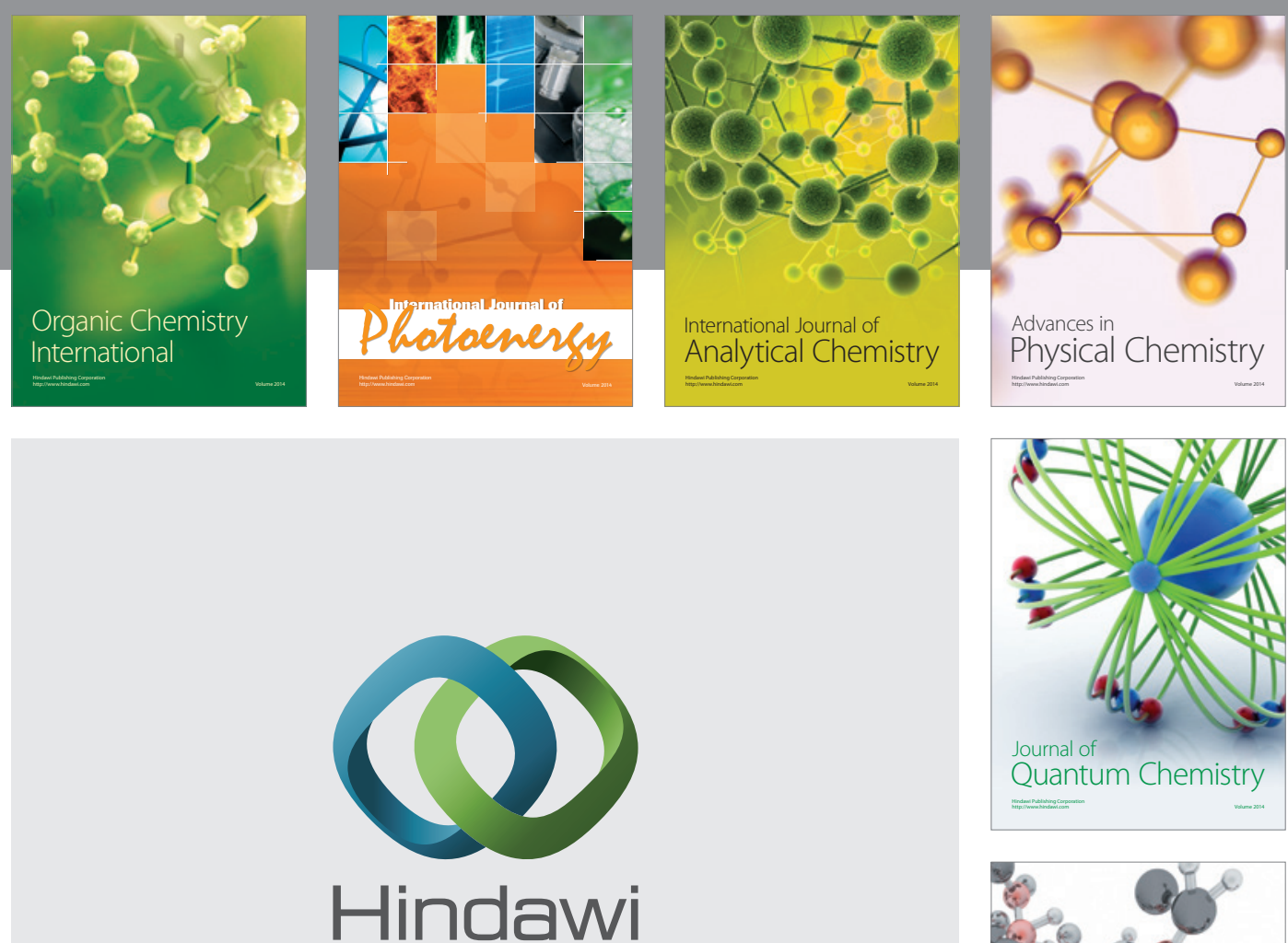

Submit your manuscripts at

http://www.hindawi.com

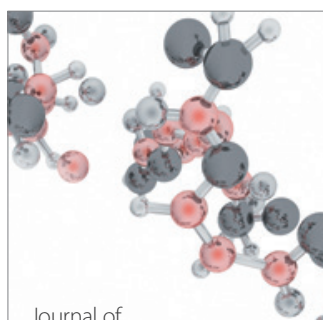

Analytical Methods

in Chemistry

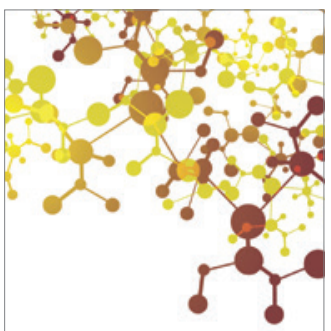

Journal of

Applied Chemistry

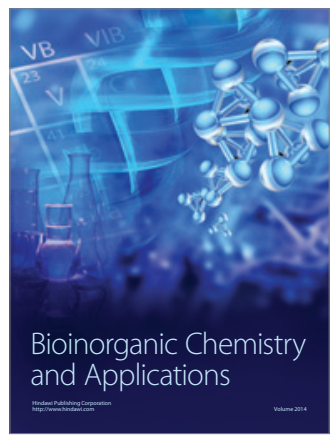

Inorganic Chemistry
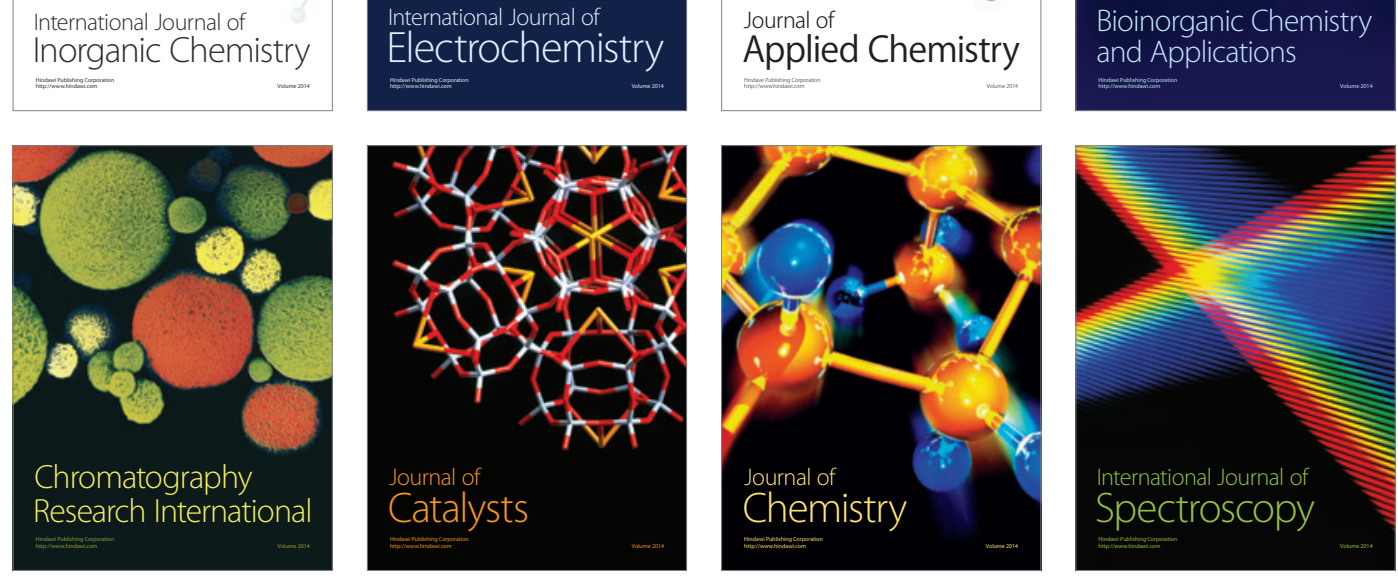